\title{
Radiographic imaging and clinical course of granular cell tumors of the breast
}

\author{
McGreevy $\mathrm{CM}^{1}$, Peters $\mathrm{SR}^{2}$, Hubbi $\mathrm{B}^{3}$ and Kalu $\mathrm{ON}^{1 *}$ \\ ${ }^{1}$ Rutgers - New Jersey Medical School, Department of Surgery, NJ, USA \\ ${ }^{2}$ Rutgers - New Jersey Medical School, Department of Pathology, NJ, USA \\ ${ }^{3}$ Rutgers - New Jersey Medical School, Department of Radiology, NJ, USA
}

\begin{abstract}
Introduction: Granular cell tumors (GCT) are rare soft tissue neoplasms of neural origin that occur in the breast in 6\% of cases. Although malignant GCTs are extremely rare; due to the unknown clinical course and radiographic similarities to invasive mammary carcinoma, wide surgical excision is currently recommended upon diagnosis of all granular cell tumors. We propose that distinct radiographic features of these tumors may identify their benign nature, thus possibly sparing surgical resection.
\end{abstract}

Method: This is a retrospective chart review of patients with GCTs of the breast from an urban tertiary care cancer center. Pathology cases over 10 years were reviewed. Seven cases of granular cell tumors were identified. Histology of GCT was confirmed with immuno-histochemical staining for S-100. Images were reviewed by a breast radiologist. Patient demographics and clinical course were collected.

Result: Seven cases of benign GCT were identified. Five cases had an initial diagnosis of GCT via core needle biopsy. Spiculated margins, posterior acoustic shadowing and lack of calcifications were radiographic features identified in the majority of cases. All surgical excisions were done via lumpectomy. Clinical follow up ranged from 3 to 129 months and no recurrences were noted.

Conclusion: Distinct radiographic characteristics were identified of GCTs, and although these findings overlap with some imaging features for invasive carcinoma, they can be used to assess for radiologic-pathologic concordance when granular cell tumors are diagnosed on image guided core biopsy. Thus, it may be feasible to monitor granular cell tumors conservatively with follow up imaging versus surgical excision.

Highlights

- Granular cell tumors of the breast are rare and most oftentimes benign.

- Distinct radiographic characteristics of granular cell tumors have been identified

- No recurrences were noted after resection, even when margins were positive

- A radiologic-pathologic concordant diagnosis can decrease unnecessary resections

\section{Introduction}

Granular cell tumors (GCTs) are neoplastic lesions of neural origin. First described by Abrikossoff in 1926 [1], GCTs can develop on any skin or mucosal surface, with the most common sites being the head, neck, trunk, and extremities. [2] GCTs are located in the breast in up to $6 \%$ of cases. In the breast, these tumors are usually benign with malignancy rates reported in $1-2 \%$ of cases $[3,4]$. Despite their low malignancy rate, current recommendations are for wide surgical excision upon diagnosis of all breast GCTs. This is due to the unknown clinical course and radiographic similarities between GCT and invasive mammary carcinoma. We propose that distinct radiographic features of these tumors with concordant core biopsy results, can identify their benign nature, and thus possibly spare surgical resection.

\section{Method}

This is an institutional review board approved retrospective chart review of all patients with granular cell tumors of the breast at Rutgers New Jersey Medical School in Newark, NJ. Charts were queried using the Department of Pathology database from 2005-2015, and patients with a diagnosis of granular cell tumor of the breast were abstracted. Once identified, cases were reassessed by a breast pathologist. Histology of GCT was confirmed with immune-histochemical staining for S-100 protein. Size of tumor and margin status was collected. Margins were defined as negative $(>1 \mathrm{~mm})$, close $(\leq 1 \mathrm{~mm})$ or positive if tumor was present at the margin [5]. Determination of malignancy was assessed using the previously validated Fanburg-Smith criteria [6]. Malignancy is defined as at least 3 of the following characteristics: necrosis, spindling, vesicular nuclei with large nucleoli, increased mitotic activity (>2 mitoses/ 10 high power fields at 200x magnification), high nuclear to cytoplasmic ratio, and pleomorphism. Radiographic imaging of

*Correspondence to: Kalu ON, Rutgers - New Jersey Medical School, Department of Surgery, NJ, USA, Tel: 9738772770; E-mail: onkalu@gmail.com

Key words: breast, granular cell tumor, radiologic-pathologic concordance, screening

Received: July 03, 2019; Accepted: July 12, 2019; Published: July 15, 2019 
biphasic ultrasound and/or digital mammography were reviewed for each case by a breast radiologist. Ultrasound and mammographic features of each tumor were reported. Patient demographics and clinical course were reviewed and documented. Patients' charts were reviewed for evidence of recurrence. Evaluation for recurrence was done at routine follow-up visits via clinical breast exams and screening mammograms in age appropriate patients. Results of most recent clinical exams and mammograms were reviewed and documented.

\section{Result}

Seven patients with GCT were identified from the pathology database over the allotted time period. Pathological review classified all tumors as benign. Patient demographics, imaging characteristics, tumor size, and margin status can be found in Table 1. All patients were of African American descent between the ages of 20 and 58. There was one male patient who did not have preoperative imaging and was lost to follow up after excision. Six patients had preoperative breast imaging; 4 had both digital mammography and biphasic ultrasound examinations and 2 had only biphasic ultrasound examination. The majority of masses had distinct radiographic characteristics; spiculated margins, posterior acoustic shadowing, and no calcifications present (Figure 1). All images were characterized as either BI-RADS 4 or 5. All but one patient with preoperative imaging had a preoperative core needle biopsy consistent with benign granular cell tumor. Six cases were solitary; and one patient having multi-centricity with masses in the breast and ipsilateral axilla. All masses were removed via lumpectomy or wide excision. The tumors had a mean size of $1.5 \mathrm{~cm}$. Two patients had close margins and two others had positive margins. There were no recurrences, or abnormalities found on breast imaging, in the cohort with mean follow up time at 44 months (range 3-129 months).

\section{Discussion}

Granular cell tumors of the breast are uncommon with most of the literature limited to case reports. Over the past 10 years, 7 patients with GCTs were identified at our institution. Here we describe their clinical course, 6 with radiographic imaging correlating with the diagnosis of GCT. Our data demonstrates the distinct radiographic characteristics of a breast GCT to be spiculated margins, posterior acoustic shadowing, and the absence of calcifications. These radiographic findings along with a concordant core needle biopsy of benign granular cell tumor were found to correlate to a pathologic diagnosis of benign granular cell tumor on surgical specimen. There was no evidence of recurrence in patients with these findings at long term follow-up, despite having close or positive margins at surgery.

Granular cell tumors are primarily benign, solitary, and less than 3 $\mathrm{cm}$. They are predominantly found in African American populations; all of which are consistent with our study. Little data is available about the clinical progression of benign granular cell tumors of the breast due to their rare nature. Current treatment recommendation is wide surgical excision, although malignant transformation of granular cell tumors are exceedingly rare [7]. There are reports of GCTs occurring either in close proximity to an invasive adenocarcinoma [8,9] or being invaded by an invasive adenocarcinoma [10]. Only three of these

Table 1. Demographic, radiographic and tumor characteristics

\begin{tabular}{|c|c|c|c|c|c|c|c|c|}
\hline Age & Sex & $\begin{array}{l}\text { Mammographic } \\
\text { Features }\end{array}$ & Ultrasound Features & BI-RADs & Pre-op Biopsy & Tumor size & Margins & $\begin{array}{c}\text { Clinical follow up } \\
\text { (months) }\end{array}$ \\
\hline 20 & Female & N/A & $\begin{array}{c}\text { Spiculated Margins } \\
\text { Hypoechoic } \\
\text { Posterior acoustic shadowing } \\
\text { Avascular }\end{array}$ & 4 & yes & $1.7 \mathrm{~cm}$ & Negative & 90 \\
\hline 21 & Female & N/A & $\begin{array}{c}\text { Well circumscribed Margins } \\
\text { Hypoechoic } \\
\text { Posterior acoustic enhancement } \\
\text { Avascular }\end{array}$ & $4 a$ & no & $1.6 \mathrm{~cm}$ & Negative & 126 \\
\hline 29 & Male & N/A & N/A & N/A & no & $1.4 \mathrm{~cm}$ & Negative & N/A \\
\hline 40 & Female & $\begin{array}{l}\text { Round mass } \\
\text { Well circumscribed } \\
\text { No calcifications }\end{array}$ & $\begin{array}{c}\text { Lobulated Margins } \\
\text { Hypoechoic } \\
\text { Posterior acoustic enhancement } \\
\text { Avascular }\end{array}$ & 4 & yes & $1.2 \mathrm{~cm}$ & Close & 3 \\
\hline 50 & Female & $\begin{array}{l}\text { Spiculated mass } \\
\text { Fatty elements } \\
\text { No calcifications }\end{array}$ & $\begin{array}{c}\text { Spiculated Margins } \\
\text { Hypoechoic } \\
\text { Posterior acoustic shadowing } \\
\text { Avascular }\end{array}$ & $4 \mathrm{c}$ & yes & $0.8 \mathrm{~cm}$ & Close & 22 \\
\hline 53 & Female & $\begin{array}{c}\text { Mass 1: } \\
\text { Spiculated mass Fatty } \\
\text { Elements } \\
\text { No calcifications } \\
\\
\text { Mass 2: } \\
\text { Spiculated mass } \\
\text { Fatty Elements } \\
\text { No calcifications }\end{array}$ & $\begin{array}{c}\text { Mass 1: } \\
\text { Spiculated Margins } \\
\text { Hypoechoic } \\
\text { Posterior acoustic shadowing } \\
\text { Avascular } \\
\text { Mass 2: } \\
\text { Spiculated Margins } \\
\text { Hypoechoic } \\
\text { Posterior acoustic shadowing } \\
\text { Vascularity present }\end{array}$ & 5 & yes & $\begin{array}{l}\text { Mass 1: } 1.5 \mathrm{~cm} \\
\text { Mass 2: } 2.3 \mathrm{~cm}\end{array}$ & $\begin{array}{l}\text { Mass } 1 \text { : Negative } \\
\text { Mass 2: Positive }\end{array}$ & 17 \\
\hline 58 & Female & $\begin{array}{l}\text { Spiculated mass } \\
\text { Fatty elements } \\
\text { No Calcifications }\end{array}$ & $\begin{array}{c}\text { Spiculated Margins Hypoechoic, } \\
\text { Posterior acoustic shadowing } \\
\text { Vascularity present }\end{array}$ & $4 c$ & yes & $1.5 \mathrm{~cm}$ & Positive & 6 \\
\hline
\end{tabular}


A.

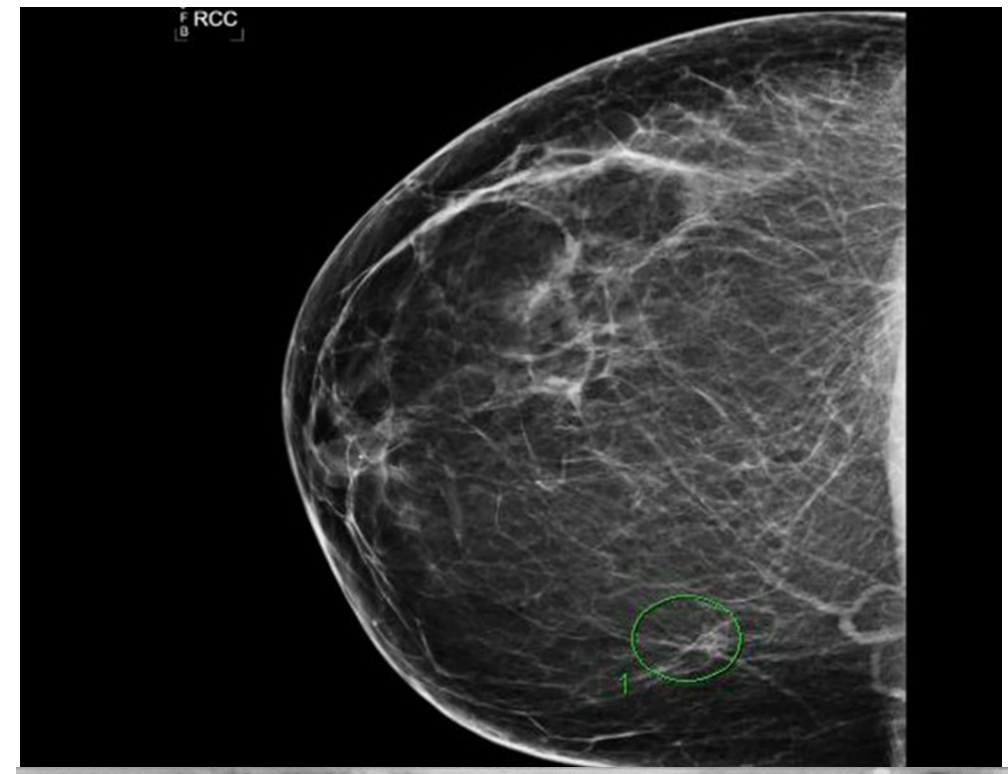

B.

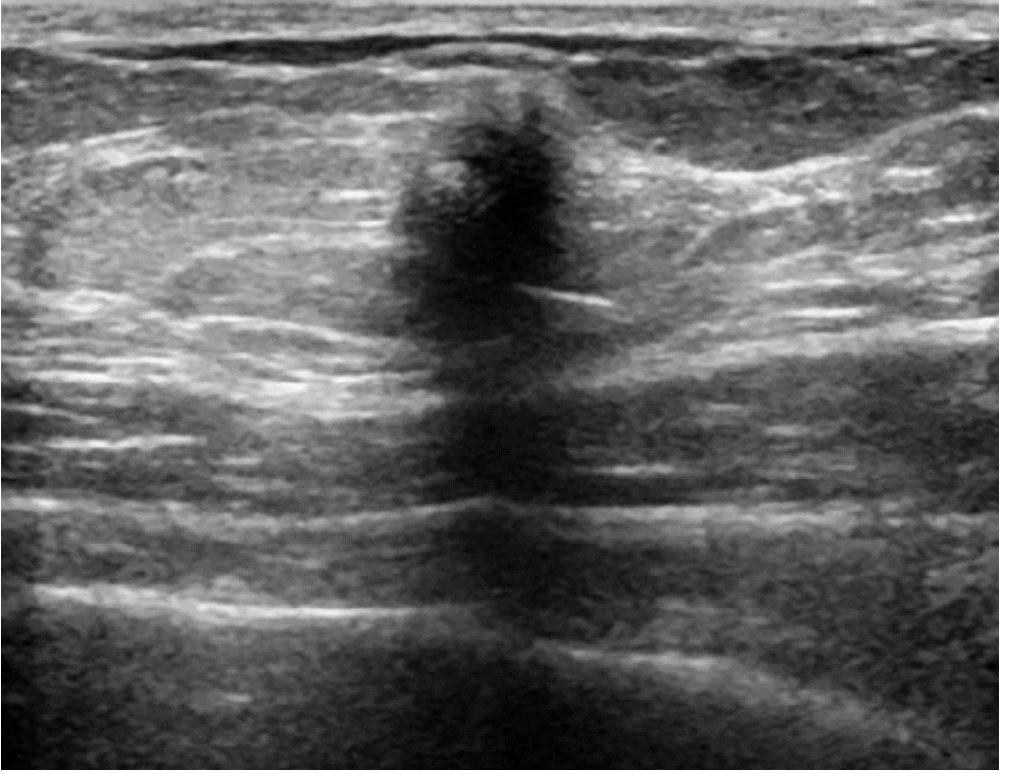

Figure 1. (A) Mammogram depicting mass without calcifications, (B) Ultrasound of a breast mass with spiculated margins and posterior acoustic shadowing

tumors have been identified in the literature $[5,9,11]$. This data is over 10 years old, and advances in imaging and pathology have likely limited the co-localization occurrences missed on pre-operative workup since that time. Some authors suggest that recurrence is associated with close or positive surgical margins, therefore suggest complete excision $[12,13]$. However, there is not any supportive data in the literature on recurrence after positive or close margins. Our data, along with another review of 13 patients by Papalas et al. [5] suggests that no recurrence was found in long term follow-up after excision, even in patients with close or positive margins. Based on these observations, we hypothesize that benign breast GCT can be treated conservatively if a concordant pathologic and radiographic diagnosis is made using the distinct radiographic features we identified. Suggested conservative management would be clinical and radiographic follow-up at six-month intervals post-diagnosis for up to 2 years. Proper patient selection for conservative management is a key factor, as compliance with routine surveillance may be an issue. Imaging stability should be confirmed by a radiologist, and any radiographic or clinical changes would prompt surgical excision. A suggested algorithm for management can be found in Figure 2.

The limitations of this study are primarily its retrospective nature and low patient cohort. Ideally a prospective study can fully support our hypothesis and treatment algorithm for benign GCTs. However, due to the rare occurrence of these neoplasms, a true prospective study may not be feasible. We are therefore proposing an alternative management for these tumors, although definitive 


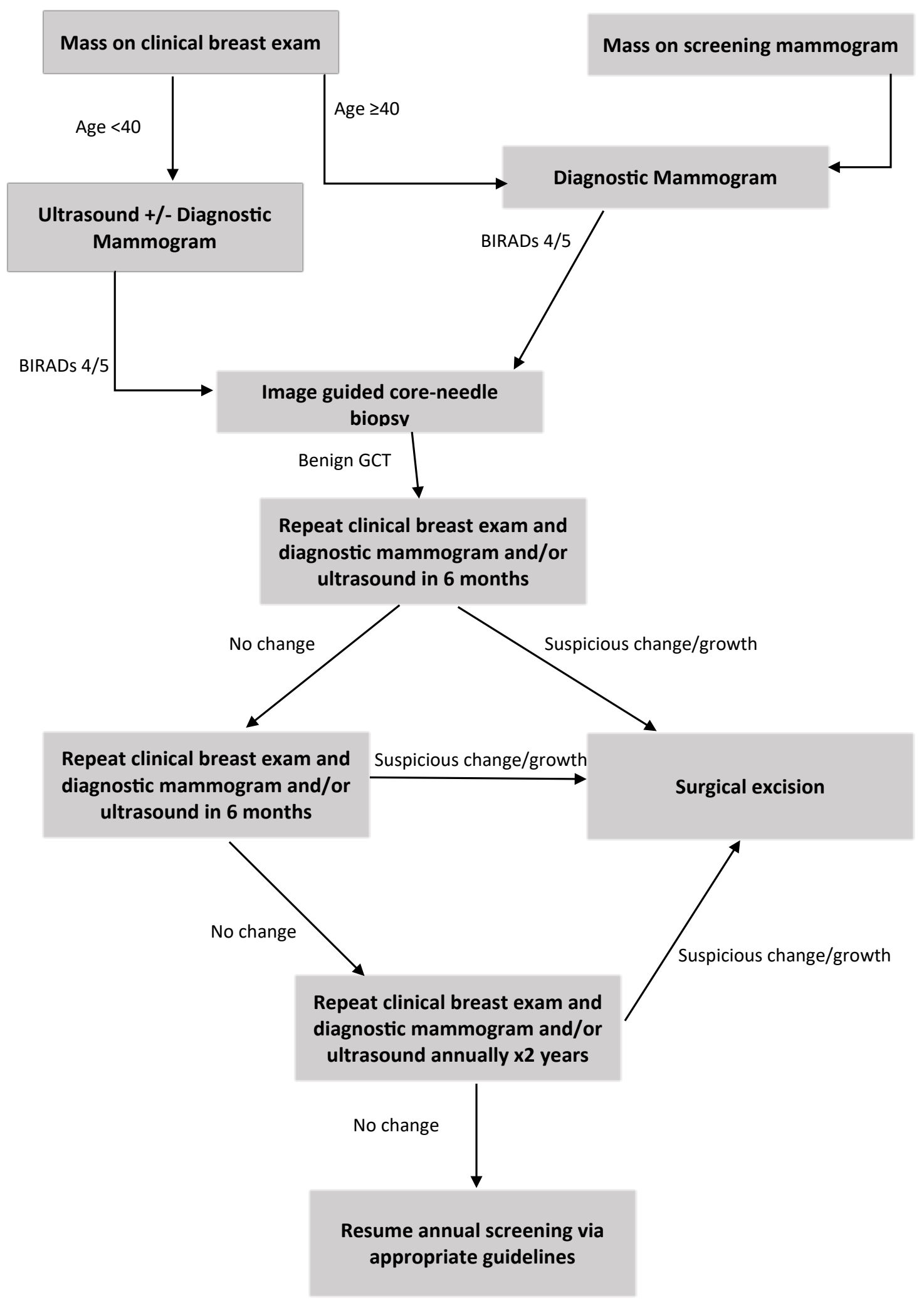

Figure 2. Treatment algorithm for Benign Granular Cell Tumor 
treatment should be left to the discretion and comfort level of the treating clinician.

\section{Conclusion}

This is the first series reviewing both imaging and the clinical course of patients with granular cell tumors of the breast. The majority of these tumors in our series have distinct radiographic characteristics; spiculated margins, posterior acoustic shadowing and a lack of calcifications. Although these findings overlap with some imaging features for invasive carcinoma, they can be used to assess for radiologic-pathologic concordance when granular cell tumors are diagnosed on image guided core biopsy. Thus, we propose it may be feasible to monitor select patients with granular cell tumors of the breast conservatively with follow up imaging and clinical breast exams versus surgical excision.

\section{Acknowledgement}

\section{Author Contributions}

Dr. Kalu and Dr. McGreevy had full access to all the data in the study and take responsibility for the integrity of the data and the accuracy of the data analysis.

Study concept and design: Kalu, McGreevy

Acquisition, analysis, or interpretation of data: Kalu, McGreevy, Hubbi, Peters

Drafting of the manuscript: McGreevy, Kalu

Critical revision of the manuscript for important intellectual content: McGreevy, Kalu, Peters, Hubbi

Statistical analysis: N/A.

Administrative, technical, or material support: McGreevy, Kalu.

Study supervision: Kalu

\section{Conflict of interest}

No conflicts of interest reported.

\section{Funders/Sponsors}

This research did not receive any specific grant from funding agencies in the public, commercial, or not-for-profit sectors.

\section{References}

1. Abrikossoff A (1926) Über Myome, Ausgehend von der quergestreiften, willkurlichen Muskulatur Virchows. Arch Pathol Anat 260: 215-33.

2. Lack EE, Worsham GF, Callihan MD, Crawford BE, Klappenbach S, et al. (1980) Granular cell tumor: a clinicopathologic study of 110 patients. J Surg Oncol 13: 301316. [Crossref]

3. Gogas J, Markopoulos C, Kouskos E, Gogas H, Mantas D, et al. (2002) Granular cell tumor of the breast: a rare lesion resembling breast cancer. Eur J Gynaecol Oncol 23: 333-34. [Crossref]

4. Gupta N, Sanchety N, Verma GS, Verma P (2015) Malignant Granular Cell Tumor of the Breast; Literature Review. Indian J Pathol Microbiol 58: 238-240. [Crossref]

5. Papalas JA, Wylie JD, Dash RC (2011) Recurrence risk and margin status in granular cell tumors of the breast: a clinicopathologic study of 13 patients. Arch Pathol Lab Med 135: 890-895. [Crossref]

6. Fanburg-Smith JC, Meis-Kindblom JM, Fante R, Kindblom LG (1999) Malignan granular cell tumor of soft tissue: diagnostic criteria and clinicopathologic correlation. Am J Surg Pathol 22: 779-94. [Crossref]

7. Scheithauer BW, Woodruff JM, Erlandson RA (1999) Tumors of the Peripheral Nervous System. Washington, DC: Armed Forces Institute of Pathology; 1999:219-282. Atlas of Tumor Pathology; 3rd series, fascicle 24.

8. Khansur T, Balducci L, Tavassoli M (1987) Granular cell tumor: clinical spectrum of the benign and malignant entity. Cancer 60: 220-222. [Crossref]

9. Tran TA, Kallakury BV, Carter J, Wolf BC, Ross JS (1997) Coexistence of granular cell tumor and ipsilateral infiltrating ductal carcinoma of the breast. South Med $J 90$ : 1149-1151. [Crossref]

10. Al-Ahmadie H, Hasselgren PO, Yassin R, Mutema G (2002) Colocalized granular cell tumor and infiltrating ductal carcinoma of the breast. Arch Pathol Lab Med 126: 731733. [Crossref]

11. Adeniran A1, Al-Ahmadie H, Mahoney MC, Robinson-Smith TM (2004) Granular cell tumor of the breast: a series of 17 cases and review of the literature. Breast $J$ 10: 528531. [Crossref]

12. Patel A, Lefemine V, Yousuf SM, Abou-Samra W (2008) Granular cell tumour of the pectoral muscle mimicking breast cancer. Cases $J$ 1: 142. [Crossref]

13. McCracken M, Hamal PB, Benson EA (1979) Granular cell myoblastoma of the breast: a report of 2 cases. Br J Surg 66: 819-821. [Crossref]

Copyright: (C2019 McGreevy CM. This is an open-access article distributed under the terms of the Creative Commons Attribution License, which permits unrestricted use, distribution, and reproduction in any medium, provided the original author and source are credited. 